\title{
Faktor Penghambat Siswa Sekolah Dasar dalam Meningkatkan Prestasi Belajar di Masa Pendemi COVID-19
}

\author{
Antonius A. Saetban \\ Pendidikan Guru Sekolah Dasar, Universitas Tribuana Kalabahi-Alor, Indonesia \\ antonsaetban@gmail.com
}

\begin{abstract}
Abstrak
Penelitian ini bermaksud untuk mengetahui faktor penghambat siswa Sekolah Dasar (SD) dalam meningkatkan prestasi belajar di masa pandemik Corona Virus Disease (COVID-19). Metode yang digunakan dalam penelitian ini adalah metode kuantitatif deskriptif. Teknik pengumpulan data dengan kuisioner. Data penelitian dianalisis dengan teknik analisis deskriptif, data dikelompokkan, diseleksi dan selanjutnya dianalisis dengan metode kuantitatif, dengan jalan menguraikan hasil penelitian lapangan. Hasil dari analisis yang akan memberikan jawaban tentang permasalahan yang ada. Hasil analisis data untuk prestasi belajar siswa diketahui ada dua faktor yang menyebabkan menurunnya prestasi belajar siswa yakni faktor intern meliputi minat membaca buku, keaktifan bertanya, waktu belajar dan frekuensi belajar setiap hari. Sedangkan faktor ekstern meliputi suasana rumah, fasilitas belajar, suasana kelas, ketepatan mengumpulkan tugas dan kondisi tempat tinggal.
\end{abstract}

Kata kunci: faktor penghambat, meningkatkan prestasi, siswa sekolah dasar.

\section{Identitas Artikel:}

Saetban, A. A. (2021). Faktor Penghambat Siswa Sekolah Dasar dalam Meningkatan Prestasi Belajar di Masa Pandemi COVID-19. Jurnal Ilmu Pendidikan (JIP) STKIP Kusuma Negara, 13(1), 58-66.

\section{PENDAHULUAN}

Pembelajaran merupakan sebuah proses adanya interaksi antara guru dengan siswa yang terjalin secara inten dan terarah guna mencapai tujuan yang telah disusun. Agar pelaksanaan pada pembelajaran berjalan dengan baik terlihat dari efektifitas dan keberhasilan pada proses interaksi dari berbagai komponen yang terlibat dalam pembelajaran. Interaksi antar komponen pembelajaran antara lain interaksi antara guru dan siswa ataupun siswa dengan siswa (Firdaus, 2020). Pandemi COVID-19 pada tahun 2020, selain mengganggu stabilitas perekonomian juga mempengaruhi sistem di bidang pendidikan setiap wilayah di Indonesia. Salah satu kebijakan pada bidang pendidikan yaitu dengan menggantikan sementara kegiatan pembelajaran di kelas. Sebagai tanggapan untuk penutupan sekolah yang disebabkan oleh COVID19, pemerintah memberikan solusi agar kegiatan belajar mengajar tetap berjalan sebagaimana mestinya.

Langkah alternatif dengan melakukan program pembelajaran jarak jauh dengan menggunakan media pembelajaran daring dan aplikasi-aplikasi yang dapat digunakan oleh guru dan siswa. Program tersebut dapat membantu pengajar agar menjangkau para siswa dari jarak jauh dan mengurangi hambatan pada bidang pendidikan. Selain itu, mengingat bahwa perubahan ke pembelajaran online secara tidak langsung berpengaruh pada daya serap peserta didik (Dewi, 2020). Penting 
untuk diperhatikan yakni komunikasi orang tua dan pendidik untuk mewujudkan kemandirian belajar peserta didik selama masa pandemic COVID-19 (Herliandry, Nurhasanah, Suban \& Kuswanto, 2020). Selanjutnya, Guru dituntut untuk inovatif dalam menggunakan pembelajaran dengan model daring. Hal ini sejalan dengan pendapat dari Tjandra (2020) bahwa guru hanya memfasilitasi dengan perpustakaan kelas, modul, buku teks, serta buku-buku pendukung, dan yang terpenting akses internet, serta menyediakan beberapa komputer untuk para siswa yang tidak membawa laptop (Anugrahana, 2020).

Jadi jelaslah pendidikan merupakan kegiatan yang dilakukan dengan sengaja agar anak didik memiliki sikap dan kepribadian yang baik, sehingga penerapan pendidikan harus diselengggarakan sesuai dengan Sistem Pendidikan Nasional berdasarkan Undang-undang Republik Indonesia No.20 Tahun 2003. Dalam sistem pendidikan nasional di Indonesia, mata pelajaran Pendidikan Agama sangat penting. Dalam rangka meningkatkan mutu pendidikan SD, masalah yang harus mendapat perhatian adalah masalah perkembangan prestasi atau cara belajar siswa dalam pelajaran. Masalah cara belajar dewasa ini perlu mendapat perhatian karena kualitas cara belajar siswa cukup memprihatinkan, dari hasil pengamatan peneliti kepada siswa SD umumnya mereka kurang memiliki kemauan belajar untuk meraih keberhasilan/prestasi belajar. Mereka umumnya hanya belajar saat menghadapi ujian, jarang sekali melakukan studi atau belajar secara rutin. Merkuri, Sudarmi \& Miswar (2017) mengemukan bahwa masih cukup banyak siswa yang mempunyai cara belajar kurang baik seperti belajar dengan waktu yang tidak teratur (tidak memiliki jadwal), belajar sambil menonton televisi atau bermain game, melakukan belajar dengan berpindah-pindah, sering terlambat masuk sekolah, dan hanya belajar pada waktu menghadapi ujian saja.

Cara belajar merupakan salah satu faktor penyebab rendahnya hasil belajar sehingga menyebabkan menurunnya mutu pendidikan. Slameto (2002) mengemukakan bahwa faktor cara belajar yang buruk merupakan penyebab masih cukup banyaknya siswa yang sebenarnya pandai tetapi hanya meraih prestasi yang tidak lebih baik dari siswa yang sebenarnya kurang pandai tetapi mampu meraih prestasi yang tinggi karena mempunyai cara belajar yang baik. Tingkat penguasaan belajar dalam mata pelajaran Pendidikan Agama Kristen dapat dilihat dari prestasi belajar. Prestasi belajar adalah penguasaan pengetahuan atau keterampilan yang dikembangkan melalui mata pelajaran, lazimnya ditunjukkan dengan nilai tes atau angka nilai yang diberikan oleh guru (Kartono, Mesra \& Azis, 2020; Johandi, Hairida \& Rasmawan, 2017). Menurut Slameto (2002) prestasi belajar dipengaruhi oleh dua macam faktor yaitu faktor intern (faktor yang bersumber dari dalam diri siswa) dan faktor eksteren (faktor yang bersumber dari luar siswa). Faktor interen meliputi faktor jasmaniah/kondisi fisiologis, faktor psikologis dan faktor kelelahan, sedangkan faktor ekstern meliputi faktor lingkungan keluarga, lingkungan sekolah dan lingkungan masyarakat.

Dengan demikian, selain sekolah dan guru, lingkungan keluarga dan orang tua juga berperan penting dalam perkembangan prestasi anak. Berdasarkan pengamatan penulis ada beberapa faktor yang menjadi pengaruh dalam kesiapan belajara dimasa pandemic, hal ini berpengaruh pada prestasi belajar siswa khusunya mata pelajaran Pendidikan Agama Kristen adalah: (1) ada sebagian siswa yang kurang merasa senang atau kurang semangat dalam belajar; (2) ada sebagian siswa yang mengukuti pelajaran semata-mata agar tidak tinggal kelas; (3) ada sebagian siswa yang 
mengikuti pelajaran bukan untuk menambah ilmu tetapi karena kewajiban sebagai siswa; (4) ada yang lebih senang bermain pada saat pelajaran pendidikan agama kristen karena mereka merasa bahwa semuanya itu sudah didapat di rumah dan kegiatan keagamaan. Selain beberapa hal di atas, ada juga faktor penghambat lain, diantaranya: (1) kurangnya fasilitas belajar di rumah dan sekolah, (2) kurangnya perhatian orasng tua, dan (3) pengaruh lingkungan tempat tinggal siswa.

\section{METODE PENELITIAN}

Penelitian ini dengan metode kuantitatif deskriptif untuk menggambarkan, menjelaskan, atau meringkaskan berbagai kondisi, situasi, fenomena, atau berbagai variabel penelitian menurut kejadian sebagaimana adanya yang dapat dipotret, diwawancara, diobservasi, serta yang dapat diungkapkan melalui bahan-bahan dokumenter (Bungin, 2005). Data yang ada di kumpul, disusun dan kemudian di analisa. Teknik pengumpulan data yaitu kuisioner, wawancara langsung dan dokumentasi. Data dianalisis dengan teknik analisis kuantitatif deskriptif. Hasil dari analisis inilah yang akan memberikan jawaban tentang permasalahan yang ada.

\section{HASIL PENELITIAN}

Berikut ini akan di bahas faktor-faktor seperti yang telah di uraikan di atas berdasarkan hasil penelitian penulis.

\section{Faktor Intern}

Variabel internal siswa terdiri dari 4 faktor yaitu minat membaca buku, keaktifan bertanya, waktu belajar, dan frekuensi belajar setiap hari.

\section{Minat Membaca}

Membaca merupakan suatu tuntutan mutlak bagi setiap siswa, karena dapat memperkaya dan memperluas pengetahuannya.namun, kenyataannya siswa SD Negeri Moru II kurang berminat dalam membaca buku.

\begin{tabular}{lcc}
\multicolumn{3}{c}{ Tabel 1. Minat Membaca Buku } \\
\hline \multicolumn{1}{c}{ Respon Siswa } & Frekuensi & Presentase (\%) \\
\hline Selalu & 8 & 26,7 \\
Sering & 7 & 23,3 \\
Kadang-Kadang & 6 & 20 \\
Tidak Pernah & 9 & 30 \\
\hline \multicolumn{1}{c}{ Jumlah } & 30 & 100 \\
\hline
\end{tabular}

Dari Tabel 1, tampak bahwa sebanyak 9 siswa atau $30 \%$ tidak pernah membaca buku pelajaran, sedangkan sebanyak 8 atau 26,7\% siswa saja yang selalu membaca buku Pelajaran.

\section{Keaktifan Bertanya}

Ketika materi yang diberikan oleh guru belum begitu dipahami, sebaiknya siswa aktif bertanya kepada guru dengan aktif bertanya, materi-materi yang belum dikuasainya ditanyakan kepada guru. 
Tabel 2. Keaktifan Sisiwa Bertanya

\begin{tabular}{lcc}
\hline Respon Siswa & Frekuensi & Presentase (\%) \\
\hline Selalu & 5 & 16.7 \\
Sering & 7 & 23,3 \\
Kadang-Kadang & 9 & 30 \\
Tidak Pernah & 9 & 30 \\
\hline \multicolumn{1}{c}{ Jumlah } & 30 & 100 \\
\hline
\end{tabular}

Dari Tabel 2, tampak bahwa sebanyak 9 siswa atau 30\% menjawab tidak pernah bertanya dalam setiap pelajaran jika materi yang diberikan oleh guru ada yang belum jelas, sedangkan sebanyak 5 siswa menjawab selalu aktif bertanya jika materi yang diberikan oleh guru belum jelas.

\section{Waktu Belajar}

Waktu belajar yang buruk seperti belajar jika ada ulangan saja dengan sistem kebut semalam tidak akan memberikan hasil yang baik, hal tersebut dapat dilihat pada Tabel 3.

Tabel 3. Waktu Belajar

\begin{tabular}{lcc}
\hline \multicolumn{1}{c}{ Respon Siswa } & Frekuensi & Presentase (\%) \\
\hline Rutin setiap hari & 2 & 6,7 \\
Setiap akan belajar Pendidikan Agama Kristen & 4 & 13,3 \\
Setiap akan ada ulangan & 20 & 66,7 \\
Tidak pernah belajar & 4 & 13,3 \\
\hline \multicolumn{1}{c}{ Jumlah } & 30 & 100 \\
\hline
\end{tabular}

Mencermati Tabel 3 bahwa sebanyak 20 siswa atau 66,7 menjawab bahwa belajar hanya pada saat akan ada ulangan saja, sedangkan hanya 2 siswa atau 6,7\% saja yang menjawab bahwa selalu rutin belajar setiap hari.

\section{Frekuensi Belajar}

Siswa yang aktif akan selalu menyempatkan untuk belajar setiap hari walaupun hanya sebentar saja, dengan frekuensi yang kurang maka materi pelajaran yang di sampaikan oleh guru akan mudah di lupakan begitu saja. Tentang frekuensi belajar siswa setiap hari tercantum dalam Tabel 4.

Tabel 4. Frekuensi Belajar Setiap Hari

\begin{tabular}{|c|c|c|}
\hline Respon Siswa & Frekuensi & Presentase $(\%)$ \\
\hline Satu sampai satu setengah jam & 3 & 10 \\
\hline 45 menit -1 jam & 2 & 6,7 \\
\hline 15 menit -45 menit & 3 & 10 \\
\hline 15 menit & 22 & 73,3 \\
\hline Jumlah & 30 & 100 \\
\hline
\end{tabular}

Dari data Tabel 4, tampak bahwa 22 siswa atau 73,3\% menjawab frekuensi belajar di rumah sebanyak 15 menit saja, sedangkan sebanyak 2 siawa atau 6,7\% menjawab frekuensi belajar di rumah sebanyak 45- 1 jam. 


\section{Faktor Eksternal}

Variabel eksternal siswa terdiri dari 5 faktor yaitu suasana rumah, fasilitas belajar, suasana kelas, ketepatan mengumpulkan tugas, dan kondisi tempat tinggal.

\section{Suasana Rumah}

Lingkungan tempat tinggal terutama rumah sangat mendukung terjadi proses belajar yang aktif. Kondisi rumah yang kurang nyaman tidak akan mendukung terjadinya belajar dirumah. Suasana rumah yang ada berdasarkan hasil penelitian terangkum dalam Tabel 5.

Tabel 5. Suasana Rumah

\begin{tabular}{lcc}
\hline \multicolumn{1}{c}{ Respon Siswa } & Frekuensi & Presentase (\%) \\
\hline Sangat mendukung & 11 & 36,7 \\
Mendukung & 3 & 10 \\
Kurang mendukung & 13 & 43,3 \\
Tidak mendukung & 3 & 10 \\
\hline \multicolumn{1}{c}{ Jumlah } & 30 & 100 \\
\hline
\end{tabular}

Dari Tabel 5, tampak bahwa 11 siswa atau 36,7\% menjawab suasaana rumah sangat mendukung untuk belajar, sebanyak 13 siswa atau 43,3\% suasana rumahnya kurang mendukung digunakan untuk belajar.

\section{Fasilitas Belajar}

Fasilitas belajar yang tidak lengkap akan menganggu proses belajar,karena proses belajar membutuhkan buku-buku penunjang dalam belajar, alat tulis menulis dan fasilitas penunjang lainnya yang dapat membuat proses belajar berlangsung dengan baik tanpa mengalami kendala/hambatan.

Tabel 6. Fasilitas belajar

\begin{tabular}{lcc}
\hline Respon Siswa & Frekuensi & Presentase (\%) \\
\hline Sangat lengkap & 4 & 13,3 \\
Lengkap & 5 & 16,7 \\
Kurang lengkap & 6 & 20 \\
Tidak lengkap & 15 & 50 \\
\hline \multicolumn{1}{c}{ Jumlah } & 30 & 100 \\
\hline
\end{tabular}

Dari Tabel 6, tampak bahwa sebanyak 15 siswa atau 50\% fasilitas yang diberikan orang tua terhadap anak-anak menunjang keberhasilan termasuk tidak lengkap sedangkan fasilitas yang lengkap yang diberikan orang tua sebanyak 4 siswa atau $13,3 \%$.

\section{Suasana Kelas}

Suasana kelas yang dekat dengan keramaian akan menganggu proses belajar mengajar, karena proses belajar mengajar membutuhkan suasana yang tenang. Suasana kelas terangkum dalam Tabel 7. 
Tabel 7. Suasana kelas

\begin{tabular}{lcc}
\hline \multicolumn{1}{c}{ Respon Siswa } & Frekuensi & Presentase (\%) \\
\hline Sangat nyaman dan kondusif & 7 & 23,3 \\
Nyaman, tenang dan kondusif & 9 & 30 \\
Kurang nyaman, kurang tenang dan kurang & 11 & 36,7 \\
kondusif & 3 & 10 \\
\hline Tidak nyaman,tidak tenang dan tidak kondusif & 30 & 100 \\
\hline \multicolumn{1}{c}{ Jumlah } & & \\
\hline
\end{tabular}

Mencermati Tabel 7 bahwa sebanyak 11 siswa atau 36,7\% menjawab bahwa kondisi kelas tidak kurang nyaman,tidak tenang dan tidak kondusif untuk proses belajar mengajar,sedangkan sebanyak 7 siswa atau 23,3\% menjawab kelas nyaman,tenang dan kondusif untuk proses belajar mengajar.

\section{Ketepatan Mengumpulkan Tugas}

Keterlambatan dalam mengumpulkan tugas akan mempengaruhi prestasi belajar siswa dan hal inilah yang menunjukan bahwa siswa tersebut tidak memiliki minat/motivasi pada pelajaran tersebut dan siswa tersebut tidak mempunyai disiplin yang baik.

Tabel 8. Ketepatan Mengumpulkan Tugas

\begin{tabular}{lcc}
\hline \multicolumn{1}{c}{ Respon Siswa } & Frekuensi & Presentase $(\%)$ \\
\hline Tepat waktu & 15 & 50 \\
Kadang - kadang & 8 & 26,7 \\
Jarang & 6 & 20 \\
Tidak pernah & 1 & 3,3 \\
\hline \multicolumn{1}{c}{ Jumlah } & 30 & 100 \\
\hline
\end{tabular}

Mencermati Tabel 8 bahwa sebanyak 1 siswa atau 3,3\% menjawab bahwa tidak pernah tepat waktu dalam mengumpulkan tugas rumah, sedangkan sebanyak 15 siswa atau $15 \%$ menjawab tepat waktu mengumpulkan tugas tepat waktu.

\section{Kondisi tempat tinggal}

Ketepatan Lingkungan yang tenang dan kondusif sangat mendukung siswa ketika sedang belajar dirumah dan sebaliknya jika suasana lingkungan tempat tinggal tidak kondusif maka proses belajar di rumah tidak dapat berlangsung dengan baik.

Tabel 9. Kondisi Tempat Tinggal

\begin{tabular}{lcc}
\hline \multicolumn{1}{c}{ Respon Siswa } & Frekuensi & Presentase (\%) \\
\hline Sangat mendukung & 13 & 43,3 \\
Mendukung & 4 & 13,3 \\
Kurang mendukung & 8 & 26,7 \\
Tidak mendukung & 5 & 16,6 \\
\hline \multicolumn{1}{c}{ Jumlah } & 30 & 100 \\
\hline
\end{tabular}

Mencermati Tabel 9 bahwa sebanyak 8 siswa atau 26\% menjawab bahwa lingkungan tempat tinggal yang ditempati sekarang ini kurang mendukung untuk 
belajar, sedangkan sebanyak 13 siswa atau 43\% menjawab bahwa lingkungan tempat tinggal mereka sangat mendukung untuk proses belajar.

\section{PEMBAHASAN}

Banyak kendala yang di temukan dalam prestasi belajar siswa di SD Negeri Moru II. Adapun kendala yang di temukan yaitu terdiri dari dua faktor. Faktor yang pertama faktor intern meliputi: minat membaca buku, keaktifan bertanya, waktu belajar dan frekuensi belajar. Sedangkan, faktor ekstern meliputi: suasana rumah, fasilitas belajar, suasana kelas, ketepatan mengumpulkan tugas dan kondisi tempat tinggal, hal ini dapat diatasi dengan cara-cara sebagai berikut.

\section{Faktor internal}

Siswa harus memiki rasa gemar atau minat dalam membaca buku karena dengan membaca siswa dapat memperkaya dan memperluas pengetahuannya serta dapat meningkatkan prestasi belajar. Selain itu, rasa percaya diri dan keberanian yang kuat yang dimiliki siswa akan mempermudah dalam memberikan pertanyaan skaligus membuat siswa selalu aktif dalam memberikan pertanyaan, karena dengan bertanya siswa dapat memahami pelajaran yang diterima serta dapat menambah wawasan siswa dalam meningkatkan prestasi belajar. Selanjutnya, siswa harus dapat mengatur waktu belajarnya dengan baik, karena keberhasilan siswa dalam belajar di pengaruhi oleh waktu belajar siswa itu sendiri hal ini, juga perlu perhatian secara baik dari guru dan orang tua.

\section{Minat Membaca Buku}

Motivasi seseorang akan sesuatu sangat mempengaruhi hasil yang di capai. Siswa yang kurang motivasi terhadap pelajaran Pendidikan Agama Kristen akan merasa cepat bosan dengan pelajaran. Sehingga minat untuk membaca buku dan berdiskusi dengan teman jika memperoleh kesulitan dalam belajar tidak akan di lakukan. Hal inilah yang menyebabkan prestasi belajar siswa menurun.

\section{Keaktifan Bertanya}

Dengan aktif bertanya maka hal-hal yang belum jelas akan dapat terjawab. Namun jika dalam belajar menemui suatu kesulitan dan di sekolah tidak mau bertanya kepada guru mata pelajaran, maka permasalahan tersebut tidak akan dapat di pecahkan, sehingga keaktifan bertanya siswa perlu di tumbuhkan.

\section{Waktu Belajar}

Untuk memperdalam materi pelajaran yang di berikan oleh guru pada saat pelajaran Pendidikan Agama Kristen di perlukan pengulangan belajar setiap hari di rumah. Frekuensi belajar yang baik adalah selalu rutin setiap hari. Belajar hanya pada saat mau ulangan atau tes saja efektif perlu di hindari, karena sistem belajar dengan istilah kebut semalam tidak akan efektif.

\section{Faktor Eksternal}

Suasana Rumah

Suasana rumah juga merupakan faktor yang penting dalam meningkatkan prestasi belajar anak. Agar anak dapat belajar dengan baik maka perlu di ciptakan suasana 
rumah yang tenang dan tentram selain anak betah tinggal di rumah, anak juga dapat belajar dengan baik.

\section{Fasilitas Belajar}

Ketersediaan fasilitas belajar yang lengkap akan menumbuhkan motivsi yang besar bagi siswa. Ketersediaan buku yang harus di miliki oleh siswa dan buku referensi yang lengkap dalam jumlah yang cukup akan mempermudah siswa dalam mencari referensi yang di berikan oleh seorang guru, karena dengan membaca referensi yang banyak maka wawasan seorang siswa akan semakin luas sehingga buku referensi yang kurang dan bahkan kadang-kadangtidak ada sama sekali akan mempengaruhi hasil belajar siswa.

\section{Suasana Kelas}

Proses belajar mengajar di perlukan suasana yang nyaman, tenang dan kondusif. Karena suasana kelas yang ramai dan penuh suara gaduh di sana sini akan menjadikan proses belajar mengajar tidak akan dapat berjalan dengan normal. Suasana yang nyaman dan tenang perlu perlu di ciptakan dari semua elemen sekolah. Jika terjadi jam kosong di mana guru tidak dapat mengajar, maka siswa di harapkan tidak masuk keluar kelas dan membuat suara gaduh. Siswa di kondisikan selalu berada di dalam kelas walaupun tidak ada gurunya. Dengan begitu suasana nyaman dan tenang dapat terpelihara.

\section{Ketepatan Mengumpulkan Tugas}

Ketepatan waktu dalam mengumpulkan tugas menunjukan bahwa siswa tersebut memiliki keinginan atau minat terhadap pelajaran khususnya pelajaran Pendidikan Agama Kristen, siswa yang lambat dalam mengumpulkan tugas menunjukan bahwa siswa tersebut tidak memiliki minat terhadap pelajaran sehingga menyebabkan prestasi belajarnya menjadi menurun dan hal inilah yang perlu di perhatikan agar dapat meningkatkan prestasi belajar anak.

\section{Kondisi Tempat Tinggal}

Keadaan masyarakat juga menentukan prestasi belajar. Bila di sekitar tempat tinggal keadaan masyarakatnya terdiri dari orang-orang yang tidak terpelajar dan mempunyai kebiasaan yang tidak baik akan berpengaruh pada siswa dan sebaliknya. Pengaruh itu akan mendorong semangat siswa untuk belajar lebih giat atau sebaliknya.

\section{SIMPULAN}

Pendidikan agama sebagai bagian integral pembangunan nasional khususnya di bidang spiritual merupakan salah satu aspek penting untuk membentuk mental dan spiritualitas seseorang agar dapat menjadi pelaku pembangunan, salah satunya dinyatakan melalui peningkatan prestasi belajar siswa.

Hasil analisis data untuk prestasi belajar siswa diketahui ada dua faktor yang menyebabkan menurunnya prestasi belajar siswa yakni faktor internal dan eksternal. Untuk faktor intern, variabel minat membaca buku pada siswa sangat rendah, variabel keaktifan bertanya juga demikian, bahwa hampir sebagian siswa mengatakan tidak pernah bertanya. Sedangkan variabel waktu belajar 66,7 \% siswa 
mengatakan belajar hanya pada saat ulangan saja, variabel frekuensi belajar yang digunakan siswa hanya 15 menit saja. Selanjutnya, untuk faktor ekstern, variabel suasana rumah dikatakan kurang mendukung digunakan untuk belajar, varabel fasilitas belajar yang diberikan orang tua tidak lengkap, variabel suasana kelas dikatakan tidak nyaman, tidak tenang dan tidak kondusif saat proses belajar mengajar berlangsung, variabel ketepatan mengumpulkan tugas di katakan tidak pernah tepat waktu dalam mengumpulkan tugas dan variabel kondisi tempat tinggal dikatakan kurang mendukung untuk belajar. Dengan demikian, rendahnya prestasi belajar siswa sangat dipengaruhi oleh faktor internal dan dan faktor eksternal, untuk itu, sekolah, guru dan orang tua perlu memeberikan perhatian penuh dalam rangka meningkatkan mutu Pendidikan melalui prestasi belajar siswa.

\section{REFERENSI}

Anugrahana, A. (2020). Hambatan, Solusi dan Harapan: Pembelajaran Daring Selama Masa Pandemi Covid-19 Oleh Guru Sekolah Dasar. Scholaria: Jurnal Pendidikan dan Kebudayaan, 10(3), 282-289.

Bungin, B. (2005). Metodologi Penelitian Kuantitatif: Komunikasi, Ekonomi, dan Kebijakan Publik Serta Ilmu-Ilmu Sosial Lainnya. Jakarta: Kencana.

Dewi, W. A. F. (2020). Dampak Covid-19 terhadap implementasi pembelajaran daring di Sekolah Dasar. Edukatif: Jurnal Ilmu Pendidikan, 2(1), 55-61.

Firdaus, F. (2020). Implementasidan Hambatan Padapembelajaran Daring Di Masa Pandemi Covid 19. Utile: Jurnal Kependidikan, 6(2), 220-225.

Herliandry, L. D., Nurhasanah, N., Suban, M. E., \& Kuswanto, H. (2020). Pembelajaran pada masa pandemi covid-19.JTP-Jurnal Teknologi Pendidikan, 22(1), 65-70.

Merkuri, L. E., Sudarmi, S., \& Miswar, D. (2017). Pengaruh Cara Belajar Terhadap Prestasi Belajar IPS Kelas VII SMP Negeri 1 Sukoharjo 2016/2017. JPG: Jurnal Penelitian Geografi, 5(8), 1-12.

Slameto. (2002). Belajar dan Faktor-faktor yang Mempengaruhinya. Jakarta: Rineka Cipta.

Kartono, G., Mesra, M., \& Azis, A. C. K. (2020). Pengembangan Media Ajar Grafis Komputer Materi WPAP Dalam Bentuk E-Book Dan Video Tutorial Bagi Mahasiswa Seni Rupa. Gorga: Jurnal Seni Rupa, 9(1), 127-132.

Johandi, J., Hairida, H., \& Rasmawan, R. (2017). Pengaruh Pembelajaran Block System Terhadap Prestasi Belajar Proses Industri Kimia Siswa Kelas XI SMTI Pontianak. Jurnal Pendidikan dan Pembelajaran Khatulistiwa, 6(3), 1-13.

Tjandra, D. S. (2020). Impelementasi Pembelajaran Pendidikan Agama Kristen di Abad 21. SIKIP: Jurnal Pendidikan Agama Kristen, 1(1), 1-10. 